\section{Federal/Provincial Forest Resource Development Agreements}

Copies of the attached two letters by CIF President Claude Godbout went to all provincial premiers except PEI. Copies of Mr. Fullerton's letter to the Prime Minister went to all members of Parliament and all of the Canadian Council of Forest Ministers.

Editor

June 9, 1989

The Honourable David Peterson, Q.C., Premier of Ontario

\section{Dear Mr. Premier:}

Federal-Provincial Forest Resources Development Agreements have been in place in all provinces during the last four to five years. They involve commitments from both levels of government or more than one billion dollars over five years and have been a major source of financial support for increased levels of forest management activity in Canada.

However all of these Agreements, except the one in P.E.I. which was renewed in 1988 , either expired in March 1989 or will expire in March 1990. Those involved in the Canadian Forest Sector are concerned that, if the Agreements are not renewed, a major and vital source of funding for environmentally sound forest management will disappear, at a time when an urgent and sustained need for continued effort is recognized in every constituency in Canada.

These forest management activities are extremely crucial when one considers the widespread occurrence of forest lands and the important role of our forest resources in providing economic and social benefits. During the past few years, the public has become increasingly aware of the importance of forest management and the continued health of our forest requires that we maintain, if not accelerate, forest management efforts that have been initiated. Moreover, forest management is a key factor in maintaining and enhancing our environment.

The forestry sector has been in regular contact with the federal government concerning the renewal of the Forest Resources Development Agreements. I am pleased to enclose a copy of a letter that was sent last April to the Prime Minister of Canada from more than 40 forest organizations representing academia, industry, unions and professionals.

It is equally important that each provincial government assign high priority to the renewal of these forestry agreements. As the decision to review those agreements will be a joint federal-provincial decision, the Canadian Institute of Forestry/Institut Forestier du Canada requests that you ensure that forestry is on your priority list when negotiating with the Federal Government.

Yours truly. Claude Godbout, ing.f. President
Le 9 juin 1989

Monsieur Robert Bourassa

Premier ministre du Québec

Monsieur le Premier ministre,

Dans toutes les provinces du Canada, des ententes fédérales-provinciales sur le développement forestier ont été en place durant les quatre ou cinq dernières années. Elles impliquaient des engagements, par les deux niveaux de gouvernement, de plus d'un milliard \$ sur cinq ans et elles ont constitué le principal appui financier aux activités d'aménagement des forêts au Canada pendant cette période. Au Québec, les montants impliqués sont de plus de 300 millions \$.

Cependant, toutes ces ententes, à l'exception de celle de l'lle-du-Prince-Edouard qui a été renouvelée en 1988, sont soit venues à échéance en mars 1989 (six d'entre-elles) ou le viendront en mars 1990 (les trois autres dont le Québec). Plusiers intervants du secteur forestier canadien se sont inquiétés du fait qu'en cas de non-renouvellement de ces ententes, les activités d'aménagement des forêts verraient disparaître une source majeure de financement et risqueraient ainsi de subir un ralentissement au moment même où l'on en reconnaît l'urgence et la nécessité.

Ces activités d'aménagement forestier sont extrêmement cruciales lorsqu'on considère l'omniprésence de la forêt et le rôle important qu'ont les ressources forestières par leur apport économique et social. En effet, l'aménagement des forêts est un facteur déterminant dans le maintien et l'amélioration de notre environnement.

Le secteur forestier s'est tenu en contact étroit avec le Gouvernement fédéral au sujet du renouvellement de ces ententes de développement forestier. Vous trouverez d'ailleurs ci-inclus une copie d'une lettre qui a été acheminée en avril dernier au Premier ministre du Canada de la part de plus de 40 organisations forestières représentant les milieux universitaires, industriels, syndicaux et professionnels.

II nous apparaît également important que chaque Gouvernement provincial attache une grande priorité au renouvellement de ces ententes forestières. Comme la décision de les renouveler procède d'une démarche conjointe, I'Institut forestier du Canada/Canadian Institute of Forestry vous demande de mettre la foresterie sur votre liste de priorité lors de vos négociations avec le Gouvernement fédéral. D'ailleurs, depuis quelques années, on constate un éveil de la population aux questions forestières et l'état de notre patrimoine forestier nous commande de poursuivre et même souvent d'accélérer les efforts d'aménagement des forêts déjà entrepris.

Veuillez agréer, Monsieur le Premier ministre, l'expression de mes sentiments les meilleurs.

Claude Godbout, ing.f. Président

April 12, 1989

The Right Honourable Brian Mulroney Prime Minister of Canada

Ottawa, Ontario
Dear Prime Minister:

Federal-Provincial Forest Resources Development Agreements have been in place in all provinces for the last four to five years. They involve commitments from both levels of government of more than one billion dollars over five years and have been a major source of financial support for increased levels of forest management activity in Canada.

However all of these Agreements, except the one in P.E.I. which was renewed to 1993 , will expire in March of 1989 or 1990 . Those involved or interested in the Canadian Forest Sector are concerned that, if the Agreements are not renewed, a major and vital source of funding for environmentally sound forest management will disappear, at a time when an urgent and sustained need for continued effort is recognized in every constituency in Canada. The momentum gained by the success of the current Agreements in promoting sustainable development of our forests will be seriously threatened

These Agreements are the main vehicle for federal support of forest management activities. Although the Canadian constitution assigns jurisdiction for forest management to the provinces there is clear evidence of public support for, and a compelling economic and environmental rationale for the necessity of, federal contribution to forest management activities in Canada. The Canadian government derives, directly and indirectly, approximately four billion dollars per year in revenues form the forest sector. This amount is about equal to the forestry revenues received by the provinces. Since the principle that those who benefit from the resource should pay for its maintenance and enhancement has been widely accepted, and since the federal government shares the benefits of the forest with provincial governments and industry, the consensus is that the federal government must share in the sustainable development of the resource. Indeed the federal "Environmental Agenda" would be hollow if it did not address the forest resource as a first priority.

These views have been expressed at numerous conferences and forums by representatives of industry, professional groups, academia and the public (most notably at the C.F.A. National Forest Congress, 1986 which you addressed), and they are included in the basic principles of the National Forest Sector Strategy for Canada. The federal government was an integral force in developing this strategy, which has been adopted by the Canadian Council of Forest Ministers and endorsed by both forest industry and environmental groups.

Following an initiative taken by the Canadian Institute of Forestry/Institut Forestier du Canada, these views were endorsed at a recent meeting in Montreal chaired by the Canadian Forestry Association. By this letter, the constituent members of the Forest Sector of Canada listed below expreess their strongest support for such an initiative and urge you to consider the renewal of these Agreements as a national priority.

Sincerely yours,

W.K. Fullerton, RPF President

Canadian Forestry Association 